\title{
Glacial Isostasy: Regional—Not Global
}

\author{
Nils-Axel Mörner \\ Paleogeophysics \& Geodynamics, Stockholm, Sweden \\ Email: morner@pog.nu
}

Received 22 May 2015; accepted 15 June 2015; published 18 June 2015

Copyright (C) 2015 by author and Scientific Research Publishing Inc.

This work is licensed under the Creative Commons Attribution International License (CC BY). http://creativecommons.org/licenses/by/4.0/

(c) (;) Open Access

\begin{abstract}
The load of the continental ice caps of the Ice Ages deformed the bedrock, and when the ice melted in postglacial time, land rose. This process is known as glacial isostasy. The deformations are compensated either regionally or globally. Fennoscandian data indicate a regional compensation. Global sea level data support a regional, not global, compensation. Subtracting GIA corrections from satellite altimetry records brings-for the first time-different sea level indications into harmony of a present mean global sea level rise of 0.0 to $1.0 \mathrm{~mm} / \mathrm{yr}$.
\end{abstract}

\section{Keywords}

Glacial Isostasy, Fennoscandia, Postglacial Uplift, Uplift Cone, Subsidences Trough, Forebulge, Low Viscosity Channel Flow, Global Sea Level Data, Correcting Satellite Altimetry, Removing Global GIA Correction

\section{Introduction}

Jamieson [1] [2] understood that the Earth is not rigid and that the load of an ice cap had to deform the bedrock beneath, causing down warping and uplift in response to the glacial advance and recession. He saw the Scottish and Fennoscandian uplift as evidence of this effect; i.e. "glacial isostasy". The full evidence and description of glacial isostasy were given by De Geer [3], however, and with this paper a new epoch begun in the study of Fennoscandian uplift [4].

When it was understood that the Earth had passed cold period known as Ice Ages with expansions of continental ice caps in the Alps [5], in North America [6] and in Fennoscandia [7], the phenomena of glacial eustasy [8] and glacial isostasy [3] followed logically. Glacial eustasy implies that water is transferred to the ice caps and global sea level by consequence falls [9], later to rise when the ice caps melt in postglacial time. Glacial isostasy implies that the load of the ice caps deforms the bedrock leading the crustal subsidence, later to transform into crustal uplift in response to the vanishing load during postglacial melting [3] [4].

The lowering of global sea level also meant that the Earth's rate of rotation increased significantly [10] and that the geoid surface was deformed affecting the crustal dynamics and local sea level [11]. 
The climatic alternations between Ice Ages and Interglacials [12] are linked to a spectrum of related changes of global and local terrestrial processes as illustrated in Figure 1 [13]. In this paper, however, we will confine the discussion to the process of glacial isostasy, and the question whether this is a primarily regional phenomenon or if it has global dimensions.

Bloom [14] was the first to suggest that the process of glacial isostasy might also affect the rest of the globe via the distribution of the loading effects into the asthenosphere. Walcott [15] called attention to the fact that the postglacial glacial isostatic compensation after the vanishing of the huge ice caps in Fennoscandia and North America (and elsewhere, too) would affect the crustal compensation regionally, if it took place via a lowviscosity channel flow, whilst it would generate global compensational crustal motions if the viscosity had a linear profile (i.e. no channel flow). The discrimination between these two concepts will be the focus of the present paper.

\section{Regional vs Global Glacial Isostasy}

Figure 2 illustrates the two alternative concepts of the spatial extension of glacial isostasy (from [16]), here termed Model A and Model B, respectively.

Model A (Figure 2(a)) is based on a linear viscosity model [17]-[20], and would imply that the glacial isostatic compensation had direct global dimensions, and hence would lack a peripheral bulge (at leas a major one) surrounding the glacially depressed region. This theory was further developed into a global standard correction model [21] [22], and has even evolved into a general correction factor for present day sea level records [23].

Model B (Figure 2(b)) implies that the glacial loading and de-loading is compensated by lateral flow in a low viscosity channel and that the glacially down warped area was surrounded by a compensational forebulge. This is the classical theory of glacial isostasy in Fennoscandian [3] [24]-[29]. All data available from Fennoscandia are in favor of a low-viscosity channel flow (Figure 2(b)). The mass in the cone of absolute postglacial uplift is

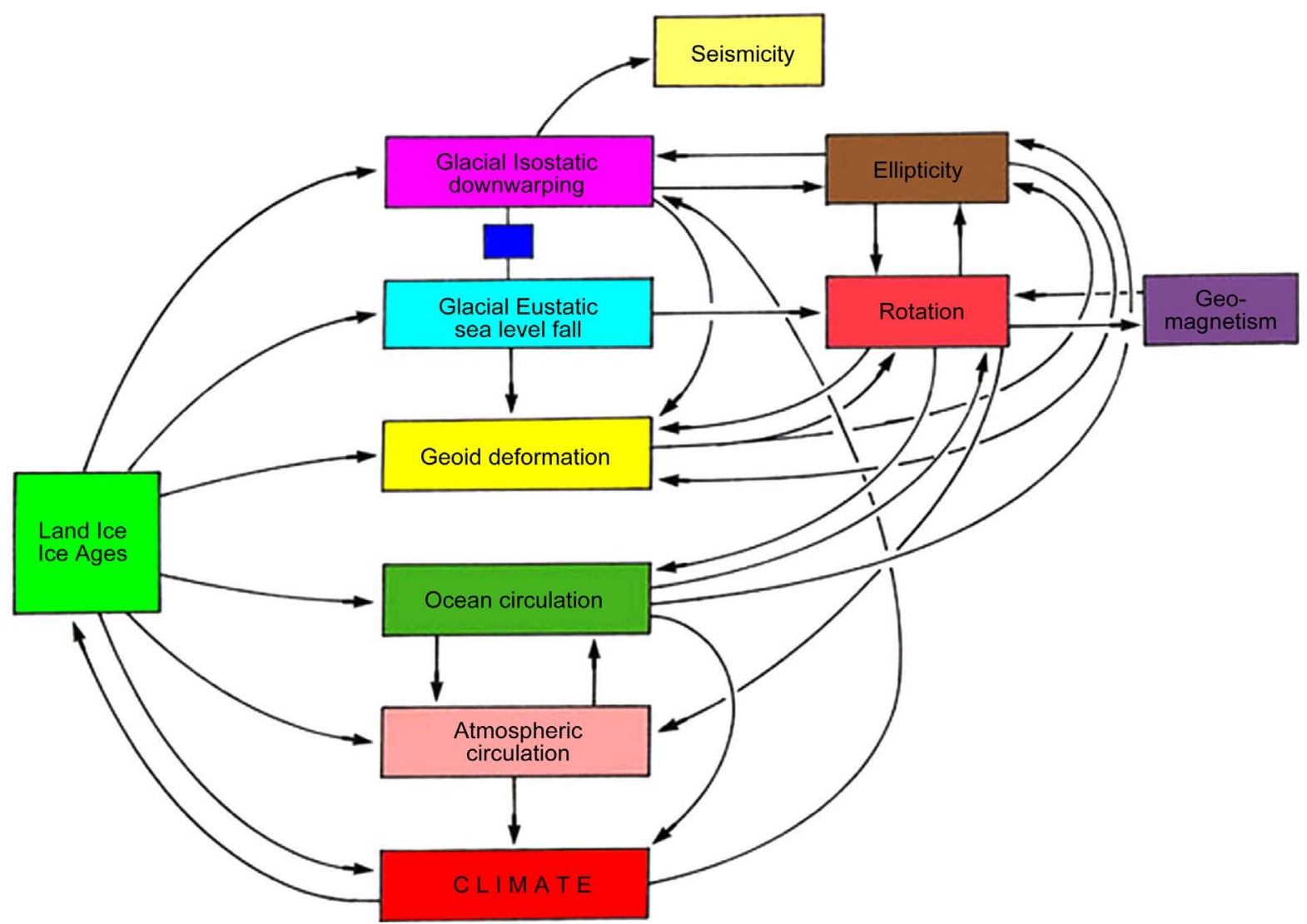

Figure 1. Interaction and feedback coupling of geodynamic processes affected by the alternations between Ice Ages and Interglacils with corresponding waxing and vanishing of continental ice caps (from [13]). 

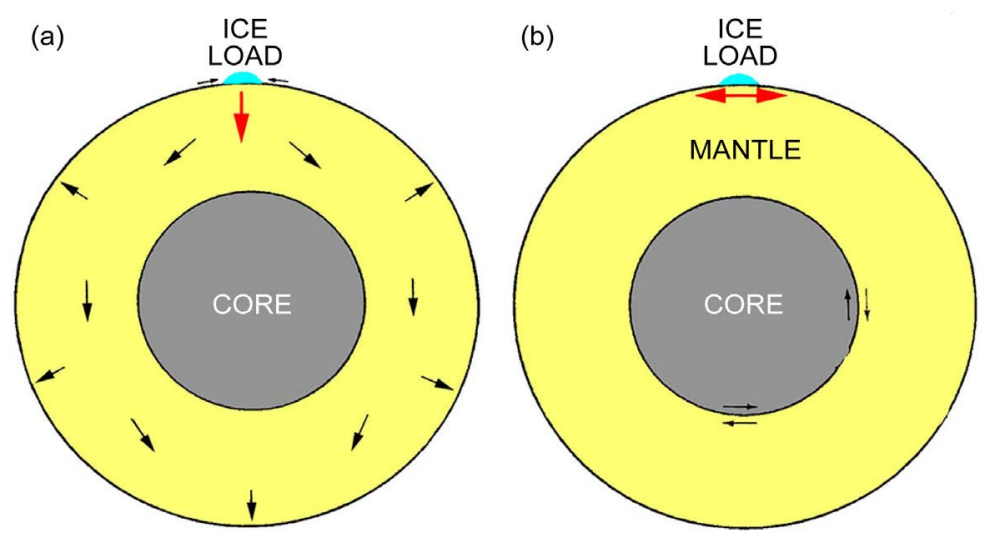

Figure 2. Global versus regional loading adjustments to glacial isostasy [16]. A: In the global loading models, the glacial loading/unloading will be transferred through the mantle and affect the coasts and sea floors all around the globe. This requires a linear viscosity in the upper mantle. B: In the regional loading model, the glacial loading/unloading is fully compensated in the region of glacial isostatic deformation via lateral mass flow in a low-viscosity upper asthenosphere channel.

the same as the mass in the surrounding peripheral subsidence trough, indicating a horizontal mass flow from the collapsing forebulge (subsidence trough) to the rising uplift cone as further discussed below (Section 3).

The determining factor for the discrimination between the two models (Figure 2) is the mode of crustal deformation in the near field [3] [27] and the mode of sea level changes in the far field [26] [30].

\section{The Fennoscandian Ice Cap and Crustal Deformation}

During the Quaternary Ice Ages large ice caps covered the Fennoscandian region [3] [4] [7] [16]. De Geer [3] was the first to show that there was clear relationship between the extension of the Fennoscandian ice cap of the Ice Age and the geometry of crustal deformation (i.e. postglacial uplift) of the Fennoscandian Shield with a maximum central uplift in the order of $200 \mathrm{~m}$ (Figure 3). Subsequent studies have, of course, sharpened the picture. Today [4] [27], we know that the absolute glacial isostatic uplift of the Fennoscandian Shield had the form of a cone with a maximum central uplift of $800 \mathrm{~m}$ (Figure 4), and being surrounded by a subsidence trough (i.e. the collapsing forebulge of the Ice Age glacial isostatic down warping of Fennoscandia). We also know that the rate of uplift right after the time of deglaciation amounted to as much as $30-40 \mathrm{~cm} / \mathrm{yr}$ [13] [27].

\subsection{Horizontal Mass Flow and Mode of Deformation}

From the uplift profiles presented at the Stockholm symposium in 1977 [31], Mörner calculated the amount of mass disappearing from the subsidence trough and appearing in the uplift cone for every 500 year from 13,000 radiocarbon years BP to the present [4] [13] [27]. Figure 5 gives this disappearance/appearance of mass. It indicates that the entire process was a matter of horizontal mass-flow. It is interesting to note that the disappearance of mass from the subsidence trough stopped some 8000 radiocarbon years BP and that the appearance of mass in the uplift cone stopped some 4500 radiocarbon years BP.

The total mass volume of the uplift cone is $7.2 \times 10^{5} \mathrm{~km}^{3}$ [27] and closely agrees with the mass in the subsidence trough (if one includes the hypothetical extension west of Norway).

Figure 6 gives an extended scheme of uplift and subsidence in the last $25 \mathrm{ka}$ in a profile from the centre of uplift out across the subsidence trough [13] [28]. The down warping of the Fennoscandian Shield in response to the glacial load of the Late Weichselian ice cap generates an uplift of a forbulge. At about 16,000 BP the forebulge begun to collacse (i.e. mass disappears), and from 13,000 BP the Fennoscandian Shield commenced its postglacial uplift. This is 3700 years before the centre of uplift actually becomes free melted [4] [27] [28] [32].

The model of uplift is given in Figure 7 (from [4] [27]); a lithosphere of high crustal rigidity and an asthenospheric channel of low viscosity where the mass-flow occurred. The asthenospheric rigidity was calculated at 2 $\times 10^{19} \mathrm{PA}$ [27]. The crustal rigidity may be as high as $10^{25} \mathrm{Nm}$ [33]. 


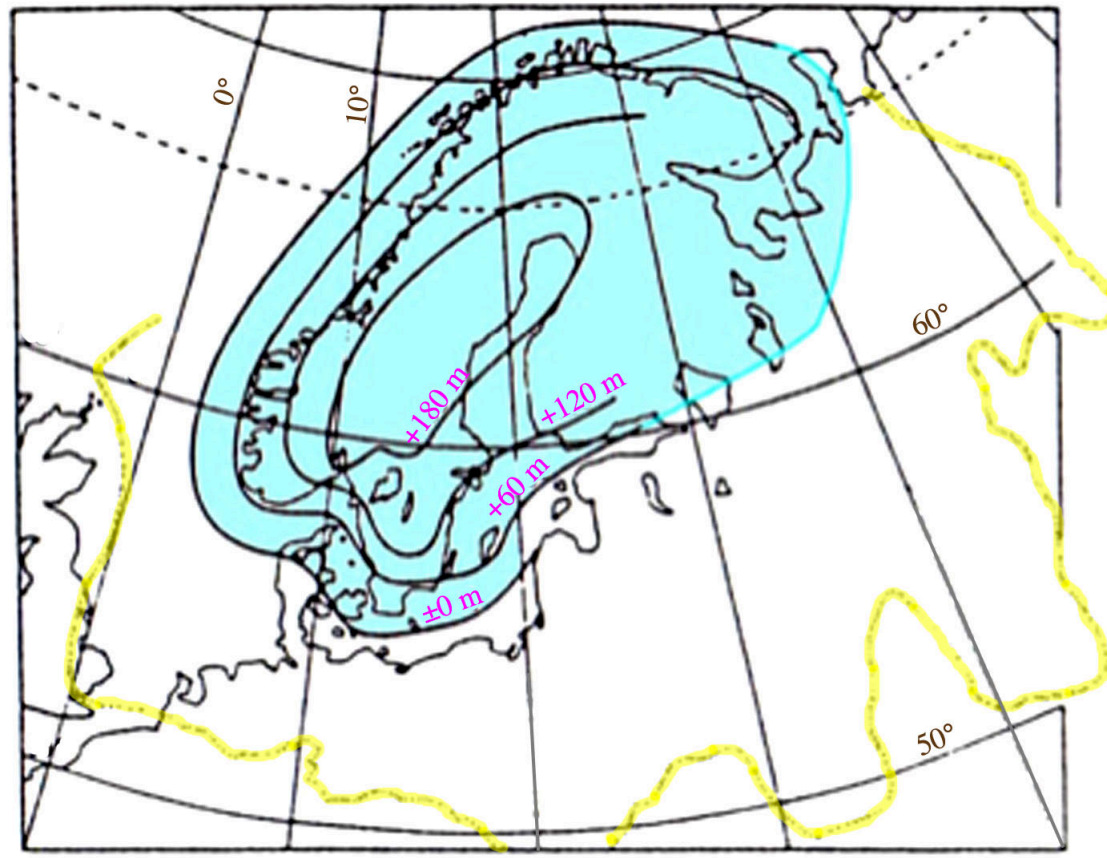

Figure 3. The isobases of postglacial uplift as recorded by the maximum sea level elevations observed (blue area) and the extension of the Ice Age glaciation (yellow line) according to De Geer [3] (with coloring [13] and later updating).

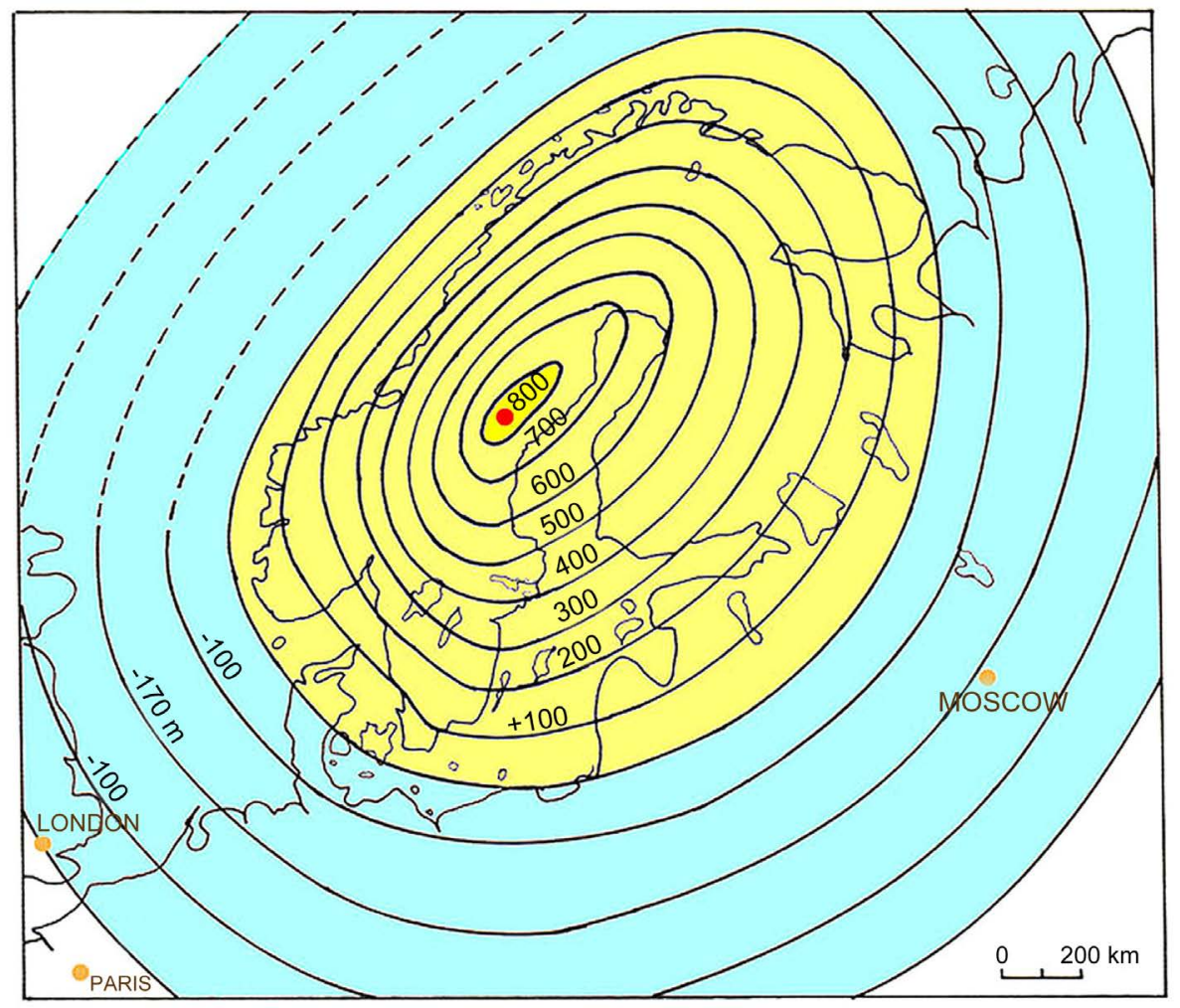

Figure 4. The amount of absolute postglacial uplift of the Fennoscandian shield (yellow), and the surrounding subsidence trough (blue); from Mörner [27] with later updating of the location of the center of uplift [13]. The mass in the uplift cone vs the mass in the subsidence trough is as $1: 1$ [27] [28]. 


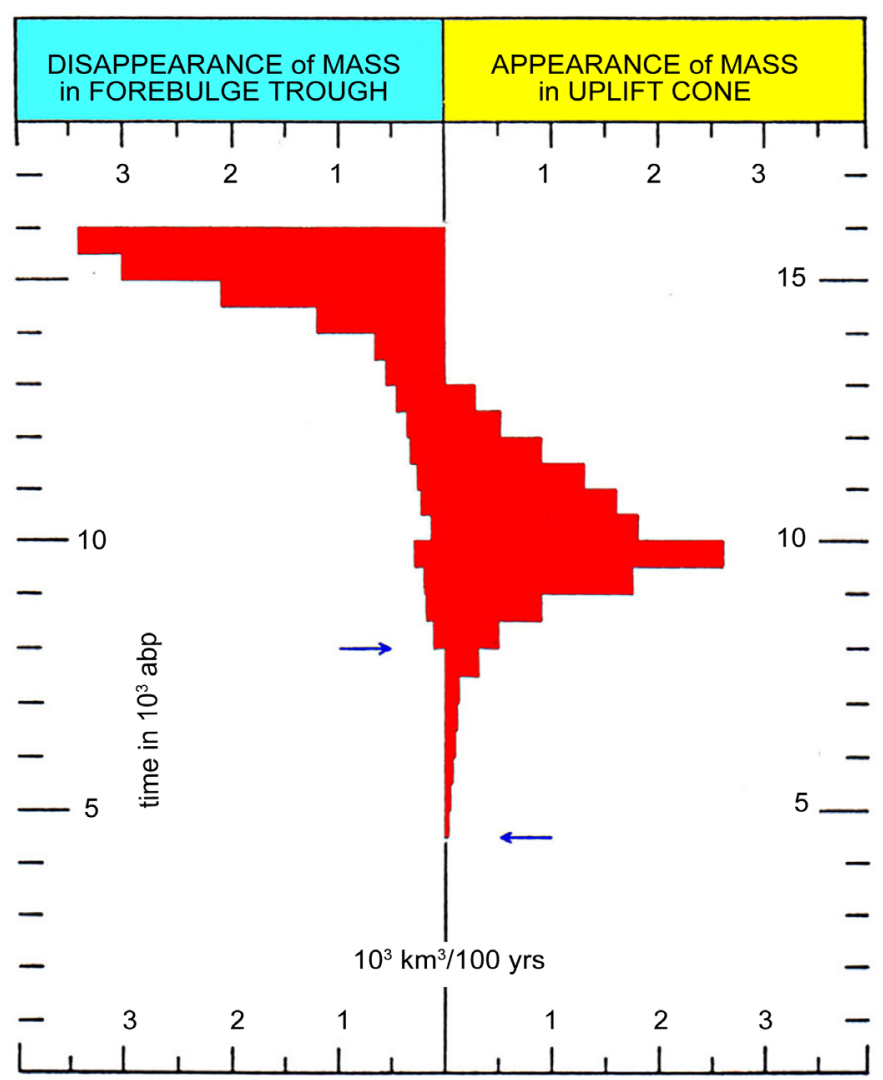

Figure 5. Mass transfer (red) from the subsidence trough to the uplift cone for every 500 years (from [4]). Arrows indicate end of mass disappearance and appearance. This diagram provides conclusive evidence of a horizontal flow of mass (i.e. a low viscosity channel flow) as a function of the process of glacial isostasy of NW Europe.

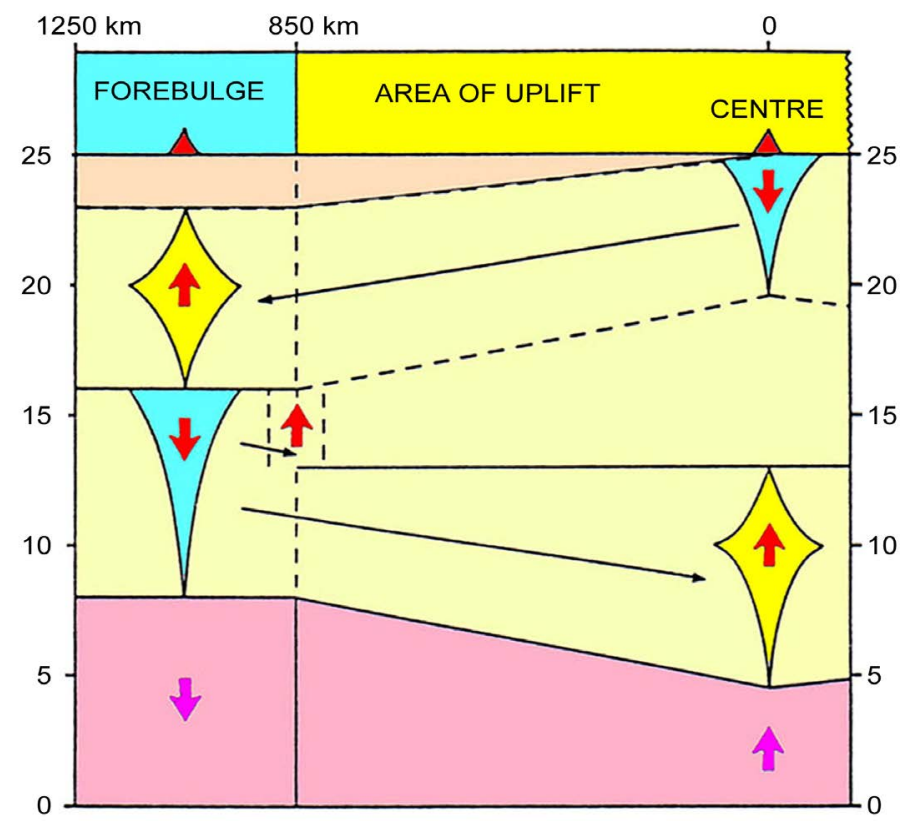

Figure 6. Uplift (yellow) and subsidence (blue), appearance/disappearance of mass (increasing/decreasing funnels) and mass transfer (thin arrow) between the area of uplift and the forebulge (from [13] [28]). 

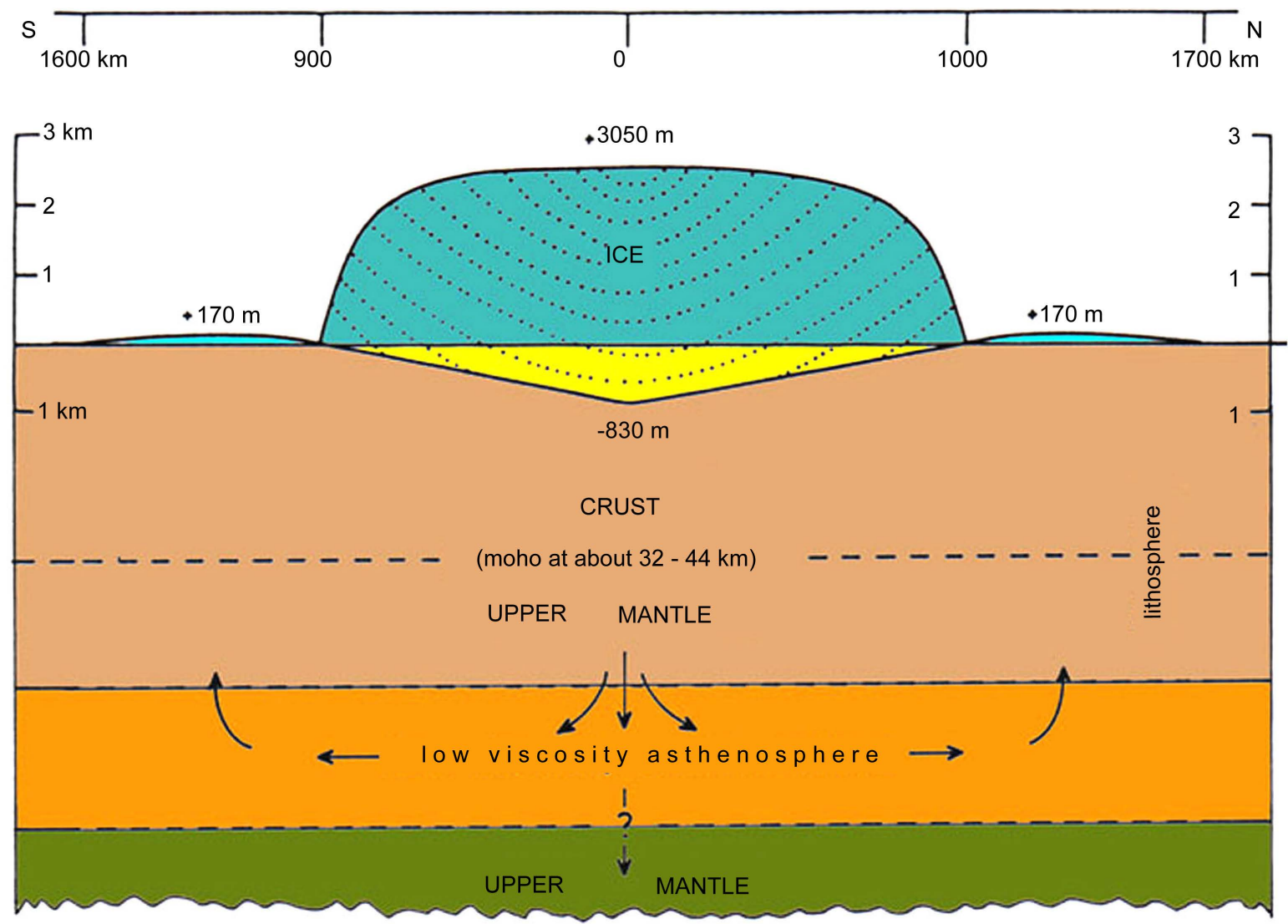

Figure 7. Model of glacial isostatic deformation [4] [27]. A $3 \mathrm{~km}$ thick ice cap deforms the crust. The down warping (peak value $\sim 830 \mathrm{~m}$ ) is compensated by horizontal mass flow in a low-viscosity asthenospheric channel. The lithospheric flexural rigidity is high (straight shorelines). The down warping (cone) is surrounded by a forebulge.

The typical glacial isostatic part of the uplift dies out with time and distance from the periphery [4] [27] [28]. Much of the uplift took part when ice still covered the land as illustrated in Figure 8. The rate of uplift reached remarkable rates at the time of free melting; estimated at $40-50 \mathrm{~cm} / \mathrm{yr}$ at the centre of uplift [27] and later actually measured at about $30 \mathrm{~cm} / \mathrm{yr}$ at a site $150 \mathrm{~km}$ south of the centre of uplift [13].

\subsection{The Linear Uplift Factor}

In the detailed sea level spectrum of the Swedish West coast and the Kattegatt Sea [26] it was not only possible to separate the isostatic and eustatic components [35], but also to identify the presence of two separate uplift mechanisms [34]. Converting the eustatically calibrated shorelines of the last 7000 radiocarbon years [26] into lines of rates of uplift and comparing these lines with the present rates of uplift from tide gauges and repeated levelling (Figure 9(a)), it became obvious [34] that the process of uplift, in facts, was composed of two different mechanisms; one typical glacial isostatic factor that exponentially died out with time and distance from the periphery, and one novel factor, responsible for the present uplift, that has remained linear for about 8000 years. This was later duplicated and verified for the Swedish east coast in a profile across the centre of uplift [37] as illustrated in Figure 9(b). At the centre of uplift the two factors are recorded as an exponentially decaying factor dying out 3500 - 4500 BP (A) and a linear factor commencing about 8000 BP (B) in Figure 8 [27] [28] [33].

The linear factor followed different rheological parameters with significantly higher viscosity and lower strain rates. It had a different centre of uplift, and an axis of tilting which has remained fixed in the Great Belt region for the last 8000 years [26] [34] [36]. It is likely to represent a sub-crustal phase boundary deformation [27] [28] [33] driven by pressure induced changes [33] [71] and/or the return from a strong vertical glacial isostatic overprinting back to long-term NW-SE compressional forces [59]. 


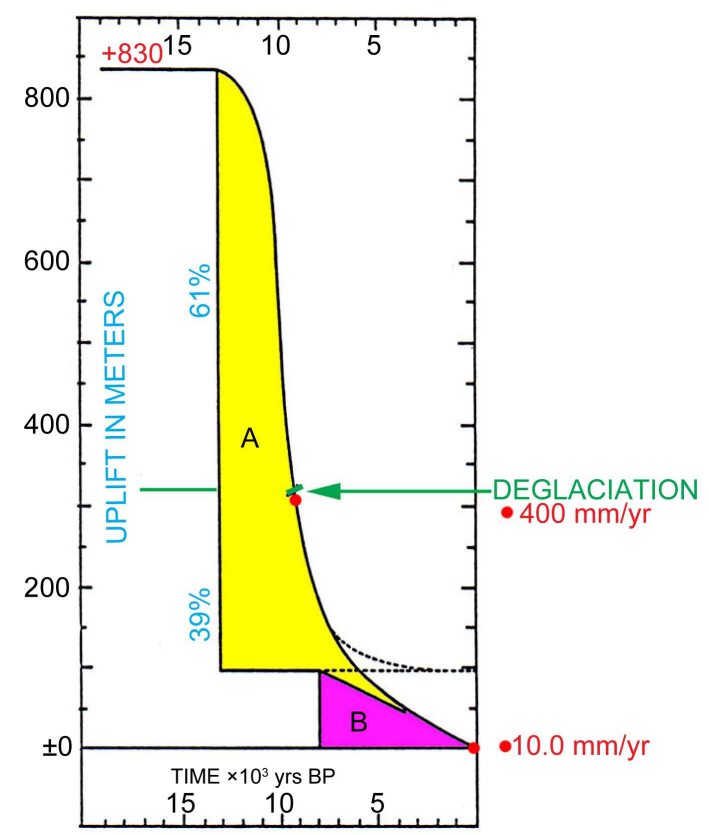

Figure 8. The glacial isostatic uplift of the Fennoscandian shield started in its central area at about 12.7-13.0 C14-ka BP [28]; not because of a thinning ice cap but because of a general change in geoid level [32]. The central area was deglaciated about 3700 years later (green mark). This implies that $61 \%$ of the uplift occurred before and only $39 \%$ after the deglaciation. The uplift is composed of two mechanisms (A and B) [4] [13] [27] [28] [33] [34].

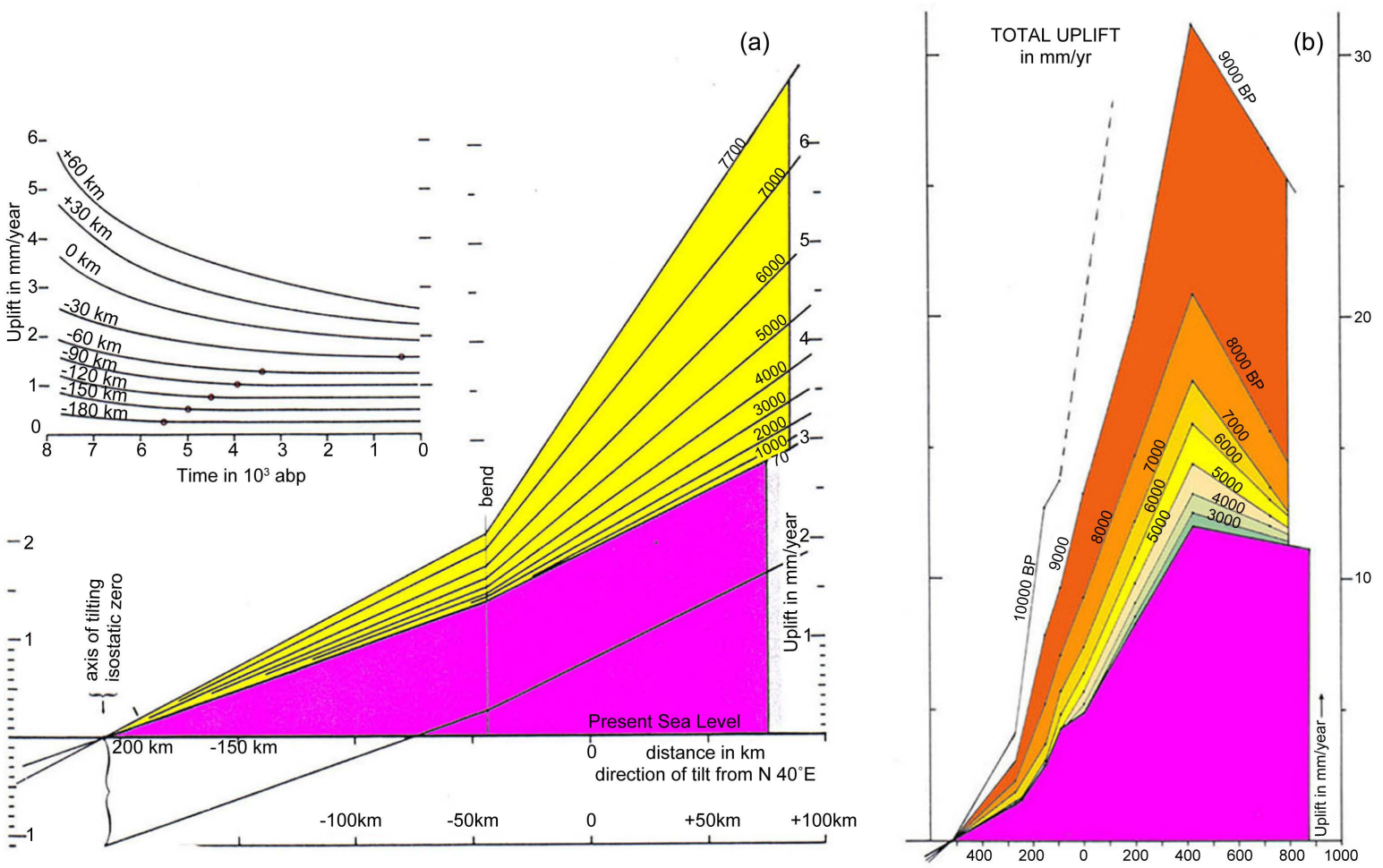

Figure 9. A (left): The West Coast profile [34] exhibiting an exponentially decaying uplift factor (yellow) and a linear factor (purple). The repeated levelling and tide gauge data (S-line) must be corrected by $1.1 \mathrm{~mm} / \mathrm{yr}$ (= the eustatic component; E) to be compatible with the shoreline spectrum. B (right): The East Coast profile [37] exhibiting an exponentially decaying, typical glacial isostatic, factor (orange-yellow) and a strong linear factor (purple). The linear factor has kept its rate constant and the axis of tilting fixed for the last 8000 years. 


\subsection{Regional Glacial Isostasy of the Fennoscandian Ice Caps}

The spectrum of elevated and tilted shorelines in Fennoscandia provides a excellent documentation of spatial and temporal mode of postglacial isostasy uplift [26] [27]. There seems to be a quite perfect balance between the uplift of the Fennoscandian uplift cone (Figure 4) and the subsidence of the surrounding subsidence trough (i.e. collapsing forebulge) as indicated by the horizontal mass motions documented in Figure 5, Figure 6, and developed into the model of glacial isostatic deformations of the Northwest European region (Figure 7). This implies a deformation adjusted by horizontal mass flow in a low-viscosity channel; i.e. a regional (not global) adjustment.

\subsection{The Geodynamic Message from NW Europe}

Consequently, the near-field observational data of a central uplift and a surrounding subsidence (Figure 7) provide records of a glacial isostatic deformation that was compensated regionally in Northwest Europe [4] [26] [27].

It was also found that $61 \%$ of the central uplift occurred subglacially before the final free melting (Figure 8). Furthermore, a second uplift mechanism commenced at around $8000 \mathrm{BP}$, and has remained lineal (i.e. constant) and with a fixed position of the axis of tilting for the last 8000 years [34] [37]. Uplift models not including these two additional facts [21] [22] are bound to fail.

\section{Far Field Sea Level Changes}

The global isostatic loading models [19]-[23] predict high Mid-Holocene sea levels in the Pacific and Indian Ocean. This does not concur with observational facts, either in the Indian Ocean or in the Pacific [16] [30]. The new sea level curve of the Maldives [38], exhibits a long term base-curve not above present sea level and a number of rapid oscillations caused by dynamic forces. In the Pacific, observed short and rapid fluctuations in sea level [39] [40] do not concur with the loading model but represent high-frequency dynamic sea surface changes. Grossman et al. [41] reconstructed the spatial distribution of Mid to Late Holocene sea level changes in the Pacific. Their reconstruction does not concur with the prediction from the global loading models, but with geoid deformation and/or changes in sea surface topography [30].

Therefore, one should be very careful in the application of model reconstruction and prediction based on proposed global loading mechanisms. This is, of course, especially true in an area like the Mediterranean dominated by tectonics and orogenic processes [16].

\section{Present Day Rates of Sea Level Changes}

Present changes in sea level are primarily measured by coastal morphology, tide gauges, and satellite altimetry, but also by considering changes in the Earth's rate of rotation (LOD) and global gravity (GRACE).

In a few places, we know the long-term crustal component [34] [36] [42] [43], and are able to separate the absolute sea level component from the relative sea level recorded by tide gauges or other means. This is, for example the case with:

Stockholm: uplift 4.9, minus tide gauge 3.8 = eustasy $1.1 \mathrm{~mm} / \mathrm{yr}$ [34] [42]

Korsör (the stable axis of tilting for 8000 years): uplift \pm 0.0 , minus tide gauge $0.9=$ eustasy $0.9 \mathrm{~mm} / \mathrm{yr}$ [34] [36]

Cuxhaven: subsidence 1.4, minus tide gauge 2.5 = eustasy $1.1 \mathrm{~mm} / \mathrm{yr}$ [36] [42]

Amsterdam: subsidence 0.4, minus tide gauge 1.6 = eustasy $1.2 \mathrm{~mm} / \mathrm{yr}$ [34] [42] [67]

Brest: crustal component $\sim 0.0$, tide gauge $1.0=$ eustasy $~ 1.0 \mathrm{~mm} / \mathrm{yr}$ [34] [42]

Venice: subsidence 2.3, minus tide gauge $2.3=$ eustasy $\pm 0.0 \mathrm{~mm} / \mathrm{yr}$ [42] [51]

Connecticut: subsidence 1.0, sea level rise 2.2 = eustasy $1.2 \mathrm{~mm} / \mathrm{yr}$ [30] [43]

Figure 10 gives a histogram of the tide gage records used by University of Colorado [44] in their global sea level assessment [42]. The mean of 182 sites (excluding a few out-layers) scattered all over the globe is $1.6 \mathrm{~mm} /$ yr [30] [42]. Because of long-term subsidence of many river mouth sites and site-specific compaction problems [42], this value may, in fact, represent a slightly too high value. The key sites here discussed provide values of about $0.0 \mathrm{~mm} / \mathrm{yr}$, and the Kattegatt and North Sea records give firm values around $1.0 \pm 0.1 \mathrm{~mm} / \mathrm{yr}$ [36] [42].

This data set is in deep conflict with the high rates proposed by the IPCC [45] [46] and satellite altimetry [47] 


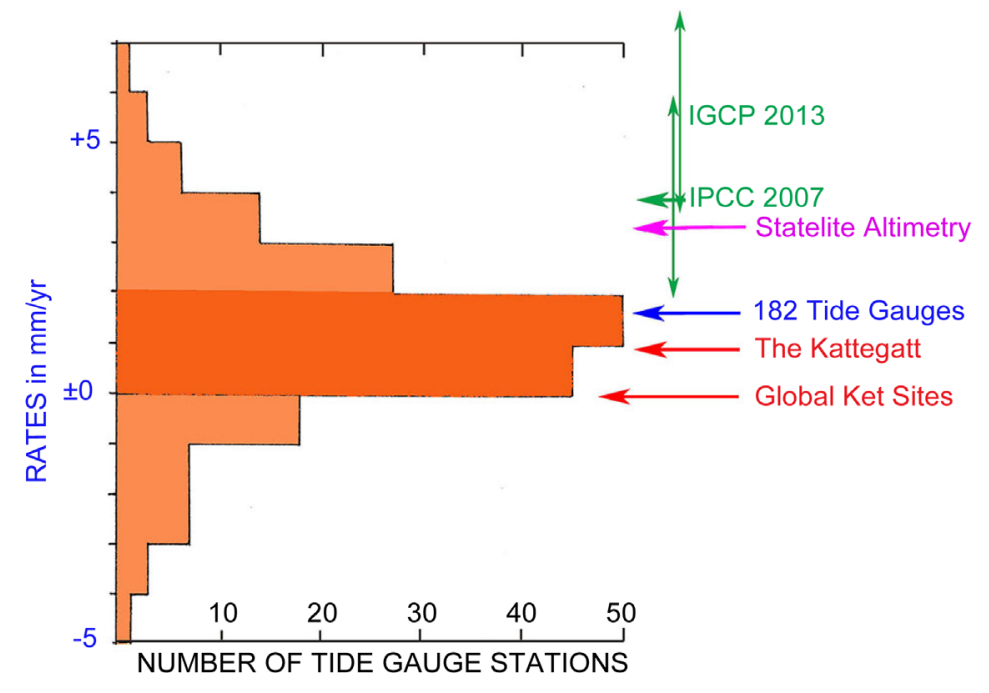

Figure 10. Spectrum of sea level rate estimates [30] [42]: observations at global key sites $( \pm 0.0)$, the Kattegatt $(0.9)$, mean of 182 tide gauges $(+1.6)$, satellite altimetry (+3.2) and IPCC model estimates. The big differences indicate errors and mistakes. The true global mean value has to be found within the zone from \pm 0.0 to $+2.0 \mathrm{~mm} / \mathrm{y}[42]$.

[48]. The differences in rates can only be understood in terms of errors and mistakes [30] [42]. The true mean global eustatic component is likely to be found in the zone ranging from $+2.0 \mathrm{~mm} / \mathrm{yr}$ to $\pm 0.0 \mathrm{~mm} / \mathrm{yr}$, and most probably in the lower half of this zone; i.e. within $1.0-0.0 \mathrm{~mm} / \mathrm{yr}$ [42]. The error was found to be in the satellite altimetry values for reasons of incorrect "corrections" [30].

Yes, something must be wrong (Figure 10), and we know what it is; viz. the corrections applied to the satellite altimetry records. After all my critics of these "corrections" [30] [36] [42] [49]-[55], neither specified nor backed up by established facts, the University of Colorado now for the first time admits that the record is "GIA corrected" [44] [48]; applied after 2011 and amounting only to $0.3 \mathrm{~mm} / \mathrm{yr}$, however [70].

In order to establish some harmony in the sea level records of Figure 10, we need to remove the global glacial isostatic (GIA) correction applied to the satellite records. In respect to the evidence of a regional (not global) glacial isostatic deformation of Fennoscandia and surrounding areas of northwest Europe (Figure 7), we must remove the whole idea of a global adjustment (Figure 2(a)).

Next question is which value we should subtract. This is not so easy, as this "correction" was not specified in the handling of satellite data. Peltier and Tushinghan [56] used a global GIA long-term sea level residual correction of $2.4 \mathrm{~mm} / \mathrm{yr}$, and Lambeck [22] a value of $1.8 \mathrm{~mm} / \mathrm{yr}$. Cazenave et al. [57] used a GIA correction of 2.0 $\mathrm{mm} / \mathrm{yr}$ for their correction of the GRACE data of 2003-2008 with a pre-corrected trend of $-0.12 \pm 0.06 \mathrm{~mm} / \mathrm{yr}$. Hence, the different corrections range from 1.8 to $2.4 \mathrm{~mm} / \mathrm{yr}$.

A simple way of removing the "GIA" factor from the satellite altimetry records would be to subtract 1.8 to 2.4 $\mathrm{mm} / \mathrm{yr}$ from the $3.3 \mathrm{~mm} / \mathrm{yr}$ by University of Colorado [48] and from $2.9 \mathrm{~mm} / \mathrm{yr}$ by NOAA [47]. In the first case, we obtain values ranging between 1.5 and $0.9 \mathrm{~mm} / \mathrm{yr}$. In the second case, we obtain values ranging between 1.1 and $0.5 \mathrm{~mm} / \mathrm{yr}$. This brings the satellite records down into the zone of likely global mean sea level changes of \pm 0.0 to $+2.0 \mathrm{~mm} / \mathrm{yr}$ [42], marked in dark orange in Figure 10 .

The original satellite record did not exhibit any trend; just a variability around a zero value from 1992 to 2000 [50] [58]. This represents a measured sequence before corrections started to be applied; first a $2.3 \mathrm{~mm} / \mathrm{yr}$ jump in 2003 and then an additional $0.8 \mathrm{~mm} / \mathrm{yr}$ jump in 2008 [30]. If one would be able to identify the original, pre-correction, sequence in the present curves of NOAA [47] and University of Colorado [48], one might obtain a better holding on what value one actually need to subtract in order fully to remove the erroneous GIA corrections.

In Figure 11, I have tried to identify the pre-correction trend 1992-2000 in the satellite altimetry record of NOAA [47], and extend this trend over the entire period of recording up to 2015. I have also added the trend of GRACE [57] of $-0.12 \mathrm{~mm} / \mathrm{yr}$ for the period 2003-2008. It runs virtually parallel to the extended pre-correction 


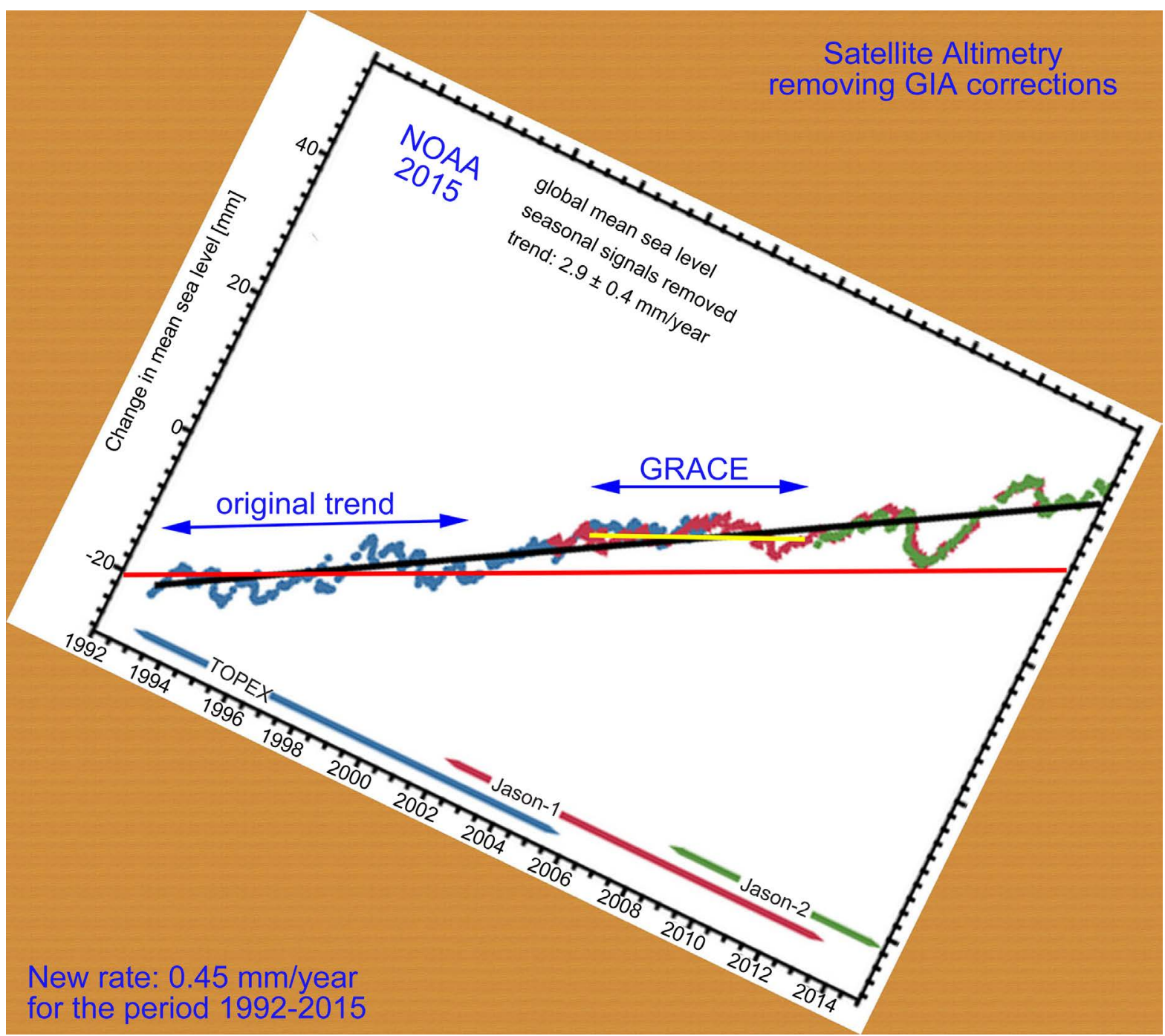

Figure 11. Removing the GIA correction from the NOAA record [47] gives a mean sea level rise of $0.45 \mathrm{~mm} / \mathrm{yr}$.

line. Then I tilted the whole graph into a horizontal position with respect to the extended pre-correction graph. I claim that this provides a good representation of the satellite altimetry record after removal of all erroneous "corrections". Now the remaining sea level trend is $0.45 \mathrm{~mm} / \mathrm{yr}$. This is in very good agreement with observational facts from tide gauges and coastal morphology from all over the globe [30] [36] [38] [42] [50] [51]. Furthermore, it is in full agreement with a previous conclusion [42] that the true global eustatic component most likely is to be found within the zone of \pm 0.0 to $+1.0 \mathrm{~mm} / \mathrm{yr}$.

In Figure 12, the same thing has been done with the satellite altimetry record of University of Colorado [48]. When the GIA corrections are removed, the remaining curve gives a rise of $0.65 \mathrm{~mm} / \mathrm{yr}$, which implies good agreements with the Figure 10 data from tide gauges and global key sites [42].

\section{Discussion and Conclusions}

The mode of glacial isostatic deformation of the Fennoscandian shield [4] [13] [26]-[28] [33] indicates—beyond doubts - that the deformation took place via horizontal mass-flow in a low-viscosity channel. This implies a glacial isostatic deformation, which is fully compensated on the regional scale (i.e. model B of Figure 2). There remains no reason to advocate forces penetrating the globe and giving rise to global glacial adjustments of coasts and seafloors all around the globe (model A in Figure 2).

The relative sea level records in Sweden (i.e. the spectrum of dated synchronous shorelines recorded over 


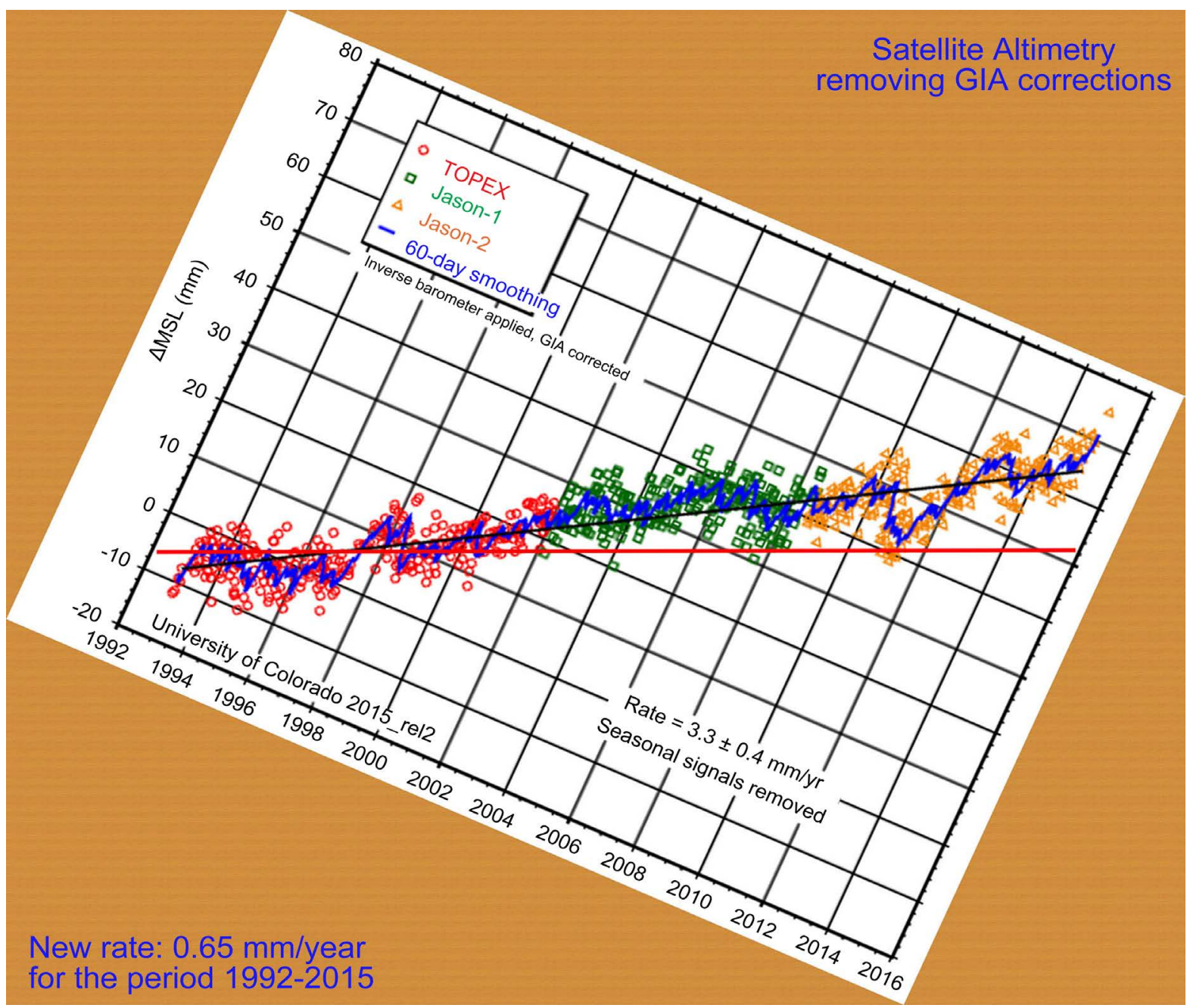

Figure 12. Removing the GIA correction from the UC record [48] gives a mean sea level rise of $0.65 \mathrm{~mm} / \mathrm{yr}$.

hundreds of kilometers and transferred in local shore level displacement curves) were successfully split up in their components of absolute glacial isostatic crustal movements and absolute eustatic sea level changes [26] [35]. The isostatic component gave fundamental information on rheological parameters [4] [27] [28] [33] and neotectonics [13] [59] [68]. The eustatic component allowed for global comparisons [26] [35] leading to the new concepts of eustasy [60] [61], the geoid theory [11], theory of differential rotation [10] [62] [63], and wellfounded views on the perspectives of future sea level changes [30] [42] [50] [67].

The rheological parameters recoded as well as the global sea level data indicate that is high time to abandon the hypothesis of a global internal response to glacial loading (Figure 2(a)).

The above-mentioned relations between relative sea level observations and resulting scientific outcome are illustrated in Figure 13 from [13].

Recent investigation of the rheological character of the upper mantle record the presence of a low-viscosity zone [64] [65] is in full agreement with the Figure 7 model (i.e. model B of Figure 2). So, even rheological data from outside northwestern Europe are in agreement with the presence of a low-viscosity channel contradicting a linear viscosity profile as required for global transfer of glacial isostatic loading (model A of Figure 2). This supports an abandoning of the globally isostatic loading model, in favour of a regional glacial isostatic model.

The second test of the models [16] refers to the far-field sea level data (section 4, above). Observational facts in favour of a global isostatic loading model are lacking. It seems significant that Houston and Dean [66] comparing GIA predictions [23] and actual tide gauge records at 147 far-field sites found "remarkably little correlation”. 


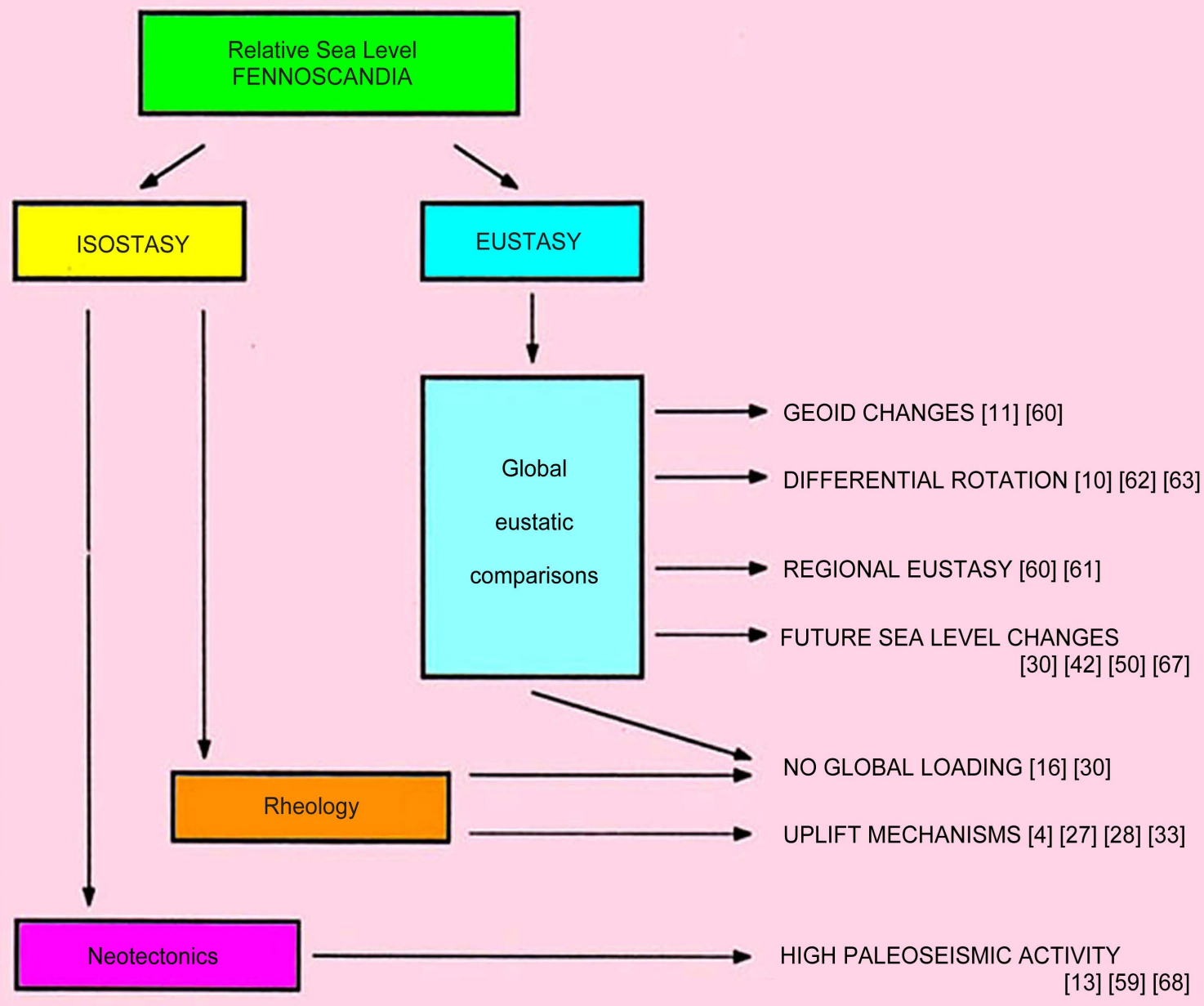

Figure 13. Separation of isostasy and eustasy from observed relative sea level changes in Fennoscandia [26] [35] and its theoretical implications for a number of fundamental questions (updated from [13]).

The satellite altimetry records [47] [48] are claimed [70] to be "a proxy for ocean water volume changes", but behind the curves are unspecified "corrections" hidden, applied by NOAA [47] and CU [48] in order to obtain the product they personally assumed to be the correct "proxy of ocean water volume changes". There is a major problem, however: their satellite altimetry records differ by $100 \%$ to $800 \%$ from observed tide gauge measurements (Figure 10).

With the removal of GIA corrections (the basic long-term residual factor of $2.3 \mathrm{~mm} / \mathrm{yr}$ as well as later additional corrections) from the satellite altimetry data (Figure 11 and Figure 12), we finally obtain agreements among global tide gauge data, costal morphology data and satellite altimetry data; all agreeing on a mean global eustatic sea level factor somewhere within the zone \pm 0.0 to $+1.0 \mathrm{~mm} / \mathrm{yr}$. This is illustrated in Figure 14. The only data set which hangs far above the others is the IPCC predictions. Those data, however, refer to assumptions and model out-puts, and are, by no means, anchored in observational facts.

The final and general conclusion of this paper is firm and says: it is high time to abandon the idea of global isostatic adjustment, and to stop all kinds of GIA corrections of records of sea level changes (i.e. satellite altimetry, GRACE, tide gauges, etc.).

\section{Acknowledgements}

At the IUGG meeting in 1975 in Grenoble, France, the organization committee of the Geodynamics Project 


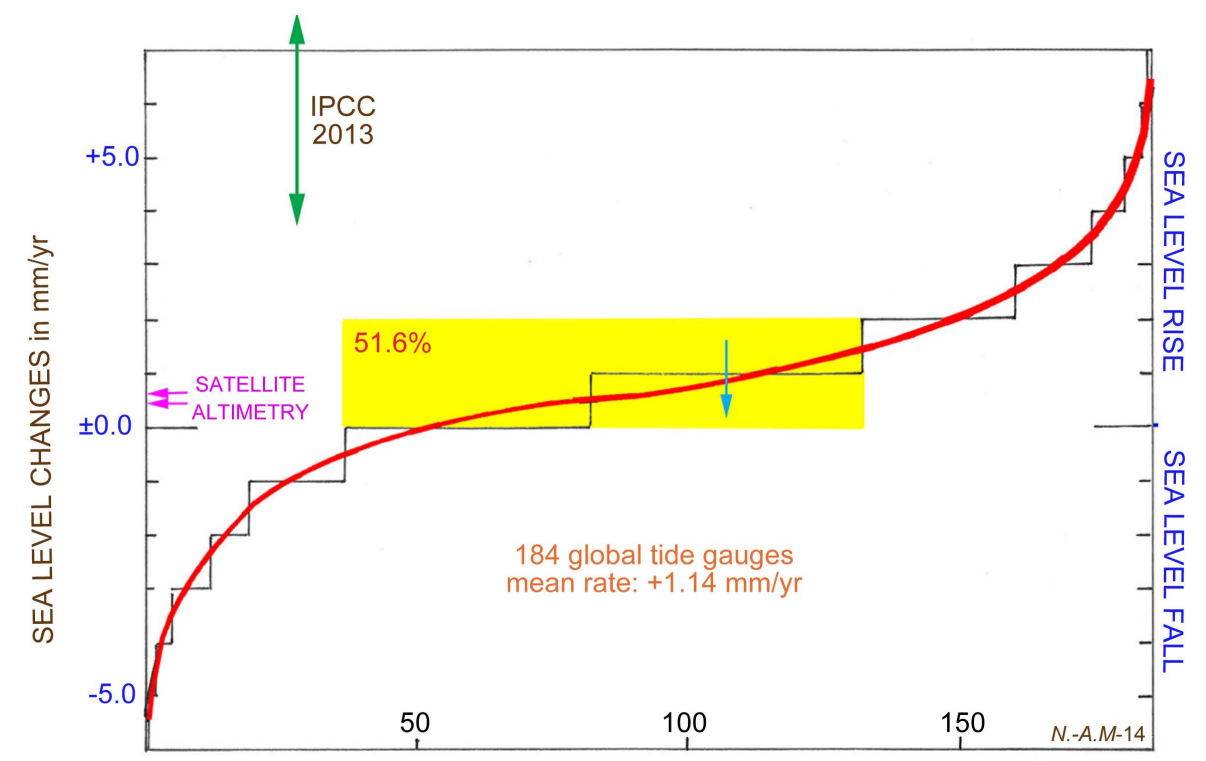

NUMBER OF GLOBAL TIDE GAUGES

Figure 14. The new spectrum of sea level changes after removal of erroneous "corrections" applied to the satellite altimetry records [47] [48]. Yellow zone gives the peak values of recorded tide gauge rates. Blue arrow indicates that several of those sites refer to subsiding sites overestimating the eustatic factor [30] [50] [69]. Now the different records of sea level changes (i.e. tide gauges, coastal morphology and satellite altimetry) give a congruent picture of a mean global sea level rise within the zone ranging from \pm 0.0 to $+1.0 \mathrm{~mm} / \mathrm{yr}$ (cf. Figure 10); only the IPCC estimates hanging above "in the air".

asked me to arrange a meeting and excursion on the Fennoscandian uplift and related topics in 1977. The proceedings of this meeting became the benchmark book on "Earth Rheology, Isostasy and Eustasy" (Mörner, ed., Wiley \& Sons, 1980). The work continued at the unit of Paleogeophysics \& Geodynamics at Stockholm University, visited by numerous scientists and the organizer of major international excursions on uplift, neotectonics and Paleoseismicity $(1999,2008)$. I am indebted to two excellent reviews.

\section{References}

[1] Jamieson, T.F. (1865) On the History of the Last Geological Changes in Scotland. Journal of the Geological Society London, 21, 161-204. http://dx.doi.org/10.1144/GSL.JGS.1865.021.01-02.24

[2] Jamieson, T.F. (1882) On the Cause of the Depression and Re-Elevation of the Land during the Glacial Period. Geological Magazine (Decade II), 9, 400-407.

[3] De Geer, G. (1888) Om Skandinaviens nivåförändringar under Quartärperioden. Geologiska Föreningens i Stockholm Förhandlingar, 10, 366-379 (1888) \&12, 61-110 (1890).

[4] Mörner, N.-A. (1979) The Fennoscandian Uplift and Late Cenozoic Geodynamics: Geological Evidence. GeoJournal, 3, 287-318.

[5] de Charpentier, J. (1835) Notice sur la cause probable du transport des blocs erratiques de la Suisse. Chez Carilian-Goeury, Paris. Annales des mines, 3me ser.

[6] Hitchcock, E. (1841) First Anniversary Address before the Association of American Geologists. American Journal of Science, 41, 232-275.

[7] Torell, O. (1872) Undersökningar öfver istiden. I \& II. Öfversigt Kongliga Svenska Vetenskapsakademiens Förhandlingar, 10, 25-66.

[8] Maclaren, C. (1841) The Glacial Theory of Professor Agassiz of Neuchatel. The Scotsman Office, Edinburgh. (also: American Journal of Science, 42, 346-365, 1842).

[9] Daly, R.A. (1910) Pleistocene Glaciation and the coral Reef Problem. American Journal of Science, 30, 297-308. http://dx.doi.org/10.2475/ajs.s4-30.179.297

[10] Mörner, N.-A. (1995) Earth Rotation, Ocean Circulation and Paleoclimate. GeoJournal, 37, 419-430. 
http://dx.doi.org/10.1007/BF00806932

[11] Mörner, N.-A. (1976) Eustasy and Geoid Changes. Journal of Geology, 84, 123-151. http://dx.doi.org/10.1086/628184

[12] Imbrie, J. and Imbrie, K.P. (1986) Ice Ages. Solving the Mystery. Harvard University Press, Cambridge, 224 p.

[13] Mörner, N.-A. (2003) Paleoseismicity of Sweden-A Novel Paradigm. Proceedings of the 16th International INQUA Congress, Reno, 23-30 July 2003, 1-320.

[14] Bloom, A.L. (1967) Pleistocene Shorelines: A New Test of Isostasy. Geological Society of America Bulletin, 78, 14771498. http://dx.doi.org/10.1130/0016-7606(1967)78[1477:PSANTO]2.0.CO;2

[15] Walcott, R.I. (1972) Past Sea Levels, Eustasy and Deformation of the Earth. Quaternary Research, 2, 1-14. http://dx.doi.org/10.1016/0033-5894(72)90001-4

[16] Mörner, N.-A. (2005) Sea Level Changes and Crustal Movements with Special Reference to the East Mediterranean. Zeitschrift für Geomorphologie, 137, 91-102.

[17] O’Connell, R.J. (1971) Pleistocene Glaciation and the Viscosity of the Lower Mantle. Geophysical Journal International, 23, 299-327. http://dx.doi.org/10.1111/j.1365-246X.1971.tb01823.x

[18] Cathles, L.M. (1975) The Viscosity of the Earth’s Mantle. Princeton University Press, Princeton, 386 p.

[19] Peltier, W.R. (1976) Glacial-Isostatic Adjustment-I. The Forward Problem. Geophysical Journal of the Royal Astronomical Society, 46, 605-646. http://dx.doi.org/10.1111/j.1365-246X.1976.tb01251.x

[20] Clark, J.A. (1980) A Numerical Model of Worldwide Sea Level Changes on a Viscoelastic Earth. In: Mörner, N.-A., Ed., Earth Rheology, Isostasy and Eustasy, John Wiley \& Sons, London, 525-534.

[21] Peltier, W.R. (1998) Postglacial Variations in the Level of the Sea: Implications for Climate Dynamics and Solid-Earth Geophysics. Reviews of Geophysics, 36, 603-689. http://dx.doi.org/10.1029/98RG02638

[22] Lambeck, C. (1998) On the Choice of Timescale in Glacial Rebound Modelling: Mantle Viscosity Estimates and the Radiocarbon Timescale. Geophysical Journal International, 134, 647-651. http://dx.doi.org/10.1046/j.1365-246x.1998.00597.x

[23] Peltier, W.R. (2004) Global Glacial Isostasy and the Surface of the Ice-Age Earth: The ICE-5G (VM2) Model and GRACE. Annual Review of Earth and Planetary Sciences, 32, 111-149. http://dx.doi.org/10.1146/annurev.earth.32.082503.144359

[24] Nansen, F. (1928) The Earth’s Crust, Its Surface Forms and Isostatic Adjustment. Norske Videnskabs-Akademi i Oslo, Matematikk og Naturvidenskap, 12, 1-122.

[25] van Bemmelen, R.W. and Berlage, H.P. (1935) Versuch einer mathematischen Behandlung geotektonischer Bewegungen unter besonderer Berücksichtigung der Undattionteorie. Gerlands Beiträge Geophysik, 43, 19-55.

[26] Mörner, N.-A. (1969) The Late Quaternary History of the Kattegatt Sea and the Swedish West Coast: Deglaciation, Shore-Level Displacement, Chronology, Isostasy and Eustasy. Sveriges Geologiska Undersökning, C460, 1-487.

[27] Mörner, N.-A. (1980) The Fennoscandian Uplift: Geological Data and Their Geodynamical Implication. In: Mörner, N.-A., Ed., Earth Rheology, Isostasy and Eustasy, John Wiley \& Sons, London, 251-284.

[28] Mörner, N.-A. (1991) Course and Origin of the Fennoscandian Uplift: The Case for Two Separate Mechanisms. Terra Nova, 3, 408-413. http://dx.doi.org/10.1111/j.1365-3121.1991.tb00170.x

[29] Fjeldskaar, W. and Cathles, L. (1991) The Present Rate of Uplift of Fennoscandia Implies a Low-Viscosity Asthenosphere, Terra Nova, 3, 393-400. http://dx.doi.org/10.1111/j.1365-3121.1991.tb00168.x

[30] Mörner, N.-A. (2013) Sea Level Changes: Past Records and Future Expectations. Energy \& Environment, 24, 509-536. http://dx.doi.org/10.1260/0958-305X.24.3-4.509

[31] Mörner, N.-A. (1977) The Fennoscandian Uplift: Geological Data and Their Geodynamical Implications. Proceedings of the Symposium on Earth Rheology and Late Cenozoic Isostatic Movements, Stockholm, 31 July-8 August 1977, 7992.

[32] Mörner, N.-A. (2015) Chapter 7: The Bölling/Alleröd-Younger Dryas Oscillations. In: Mörner, N.-A., Ed., Planetary Influence on the Sun and the Earth and a Modern Book-Burning, Noca Science Publishers, Hauppauge, 79-89.

[33] Mörner, N.-A. (1990) Glacial Isostasy and Long-Term Crustal Movements in Fennoscandia with Respect to Lithospheric and Asthenospheric Processes and Properties. Tectonophysics, 176, 13-24. http://dx.doi.org/10.1016/0040-1951(90)90256-8

[34] Mörner, N.-A. (1973) Eustatic Changes during the Last 300 Years. Palaeogeography, Palaeoclimatology, Palaeoecology, 13, 1-14. http://dx.doi.org/10.1016/0031-0182(73)90046-1

[35] Mörner, N.-A. (1971) Eustatic Changes during the Last 20,000 Years and a Method of Separating the Isostatic and Eustatic Factors in an Uplifted Area. Palaeogeography, Palaeoclimatology, Palaeoecology, 9, 153-181. 
http://dx.doi.org/10.1016/0031-0182(71)90030-7

[36] Mörner, N.-A. (2015) Deriving the Eustatic Sea Level Component in the Kattegatt Sea. Global Perspectives on Geography, 2, 16-21.

[37] Mörner, N.-A. (1977) Past and Present Uplift in Sweden: Glacial Isostasy, Tectonism and Bedrock Influence. Geologiska Foereningan i Stockholm. Foerhandlingar, 99, 48-54. http://dx.doi.org/10.1080/11035897709454988

[38] Mörner, N.-A. (2007) Sea Level Changes and Tsunamis. Environmental Stress and Migration over the Seas. Internationales Asienforum, 38, 353-374.

[39] Pirazzoli, P.A., Montaggioni, L.F., Salvat, B. and Faure, G. (1988) Late Holocene Sea Level Indicators from Twelve Atolls in the Central and Eastern Tuamotus (Pacific Ocean). Coral Reefs, 7, 57-68. http://dx.doi.org/10.1007/BF00301642

[40] Nunn, P. (1995) Holocene Sea-Level Changes in the South and West Pacific. Journal of Coastal Research, SI17, 311319.

[41] Grossman, E.E., Fletcher, C.H. and Richmond, B.M. (1998) The Holocene Sea-Level Highstand in the Equatorial Pacific: Analysis of the Insular Paleosea-Level Database. Coral Reefs, 17, 309-327. http://dx.doi.org/10.1007/s003380050132

[42] Mörner, N.-A. (2014) Sea Level Changes in the 19-20th and 21st Centuries. Coordinates, X:10, 15-21

[43] Mörner, N.-A. (2014) An Insult to Geology and Sea Level Research. http://joannenova.com.au/2014/10/modern-seas-unprecedented-an-insult-to-geology-and-sea-level-research/

[44] UC, University of Colorado (2013) Sea Level Research Group of University of Colorado. http://sealevel.colorado.edu/

[45] IPCC (2007) Fourth Assessment Report. The Intergovernmental Panel of Climate Change.

[46] IPCC (2013) Fifth Assessment Report. The Intergovernmental Panel of Climate Change.

[47] NOAA (2014) Laboratory for Satellite Altimetry/Sea Level Rise. http://www.star.nesdis.noaa.gov/sod/lsa/SeaLevelRise/

[48] UC, University of Colorado (2015) Sea Level Research Group of University of Colorado. http://sealevel.colorado.edu/

[49] Mörner, N.-A. (2010) There Is No Alarming Sea Level Rise. 21st Century Science \& Technology, Winter 2010/2011, $12-22$.

[50] Mörner, N.-A. (2004) Estimating Future Sea Level Changes. Global and Planetary Change, 40, 49-54. http://dx.doi.org/10.1016/S0921-8181(03)00097-3

[51] Mörner, N.-A. (2007) The Greatest Lie Ever Told. P\&G-Print, Stockholm, 20 p. (2nd Edition 2009, 3rd Edition 2010)

[52] Mörner, N.-A. (2008) Comments. Global and Planetary Change, 62, 219-220. http://dx.doi.org/10.1016/j.gloplacha.2008.03.002

[53] Mörner, N.-A. (2011) Chapter 6: Setting the Frames of Expected Future Sea Level Changes by Exploring Past Geological Sea Level Records. In: Easterbrook, D.J., Ed., Evidence-Based Climate Science, Elsevier, Amsterdam, 185-196. http://dx.doi.org/10.1016/b978-0-12-385956-3.10006-3

[54] Mörner, N.-A. (2011) Chapter 7: The Maldives as a Measure of Sea Level and Sea Level Ethics. In: Easterbrook, D.J., Ed., Evidence-Based Climate Science, Elsevier, Amsterdam, 197-209.

[55] Mörner, N.-A. (2012) Sea Level Is Not Rising. SPPI Reprint Series, December 6, 2012, 7-25.

[56] Peltier, W.R. and Tushinghan, A.M. (1989) Global Sea Level Rise and the Greenhouse Effect: Might There Be a Connection? Science, 244, 806-810. http://dx.doi.org/10.1126/science.244.4906.806

[57] Cazenave, A., Dominh, K., Guinehut, S., Berthier, E., Llovel, W., Rammien, G., Ablain, M. and Larnicol, G. (2009) Sea Level Budget over 2003-2008: A Reevaluationfrom GRACE Space Gravimetry, Satellite Altimetry and Argo. Global Planetary Change, 65, 83-88. http://dx.doi.org/10.1016/j.gloplacha.2008.10.004

[58] MEDIAS (2000) Satellite-Based Altimetry Reveals Physical Ocean. Medias Newsletter, 12, 9-17.

[59] Mörner, N.-A. (1991) Intense Earthquakes and Seismotectonics as a Function of Glacial Isostasy. Tectonophysics, 188, 407-410. http://dx.doi.org/10.1016/0040-1951(91)90471-4

[60] Mörner, N.-A. (1986) The Concept of Eustasy: A Redefinition. Journal of Coastal Research, S1, 49-51.

[61] Mörner, N.-A. (1980) The Northwest European "Sea-Level Laboratory" and Regional Holocene Eustasy. Palaeogeography, Palaeoclimatology, Palaeoecology, 29, 181-300.

[62] Mörner, N.-A. (1988) Terrestrial Variations within Given Energy, Mass and Momentum: Paleoclimate, Sea Level, Paleomagnetism, Differential Rotation and Geodynamics. In: Stephenson, F.R. and Wolfendale, A.W., Eds., Secular Solar and Geomagnetic Variations in the Last 10,000 Years, Kluwer Academic Publishers, Dordrecht, 455-478. http://dx.doi.org/10.1007/978-94-009-3011-7_29 
[63] Mörner, N.-A. (2015) Multiple Planetary Influences on the Earth. In: Mörner, N.-A., Ed., Planetary Influence on the Sun and the Earth, and a Modern Book-Burning, Nova Science Publishers, Hauppauge, 39-49.

[64] Karato, S. (2012) On the Origin of the Asthenosphere. Earth and Planetary Science Letters, 321-322, 95-103. http://dx.doi.org/10.1016/j.epsl.2012.01.001

[65] Naif, S., Key, K., Constable, S. and Evans, R.L. (2013) Melt-Rich Channel Observed at the Lithosphere-Asthenosphere Boundary. Nature, 495, 356-359. http://dx.doi.org/10.1038/nature11939

[66] Houston, J.R. and Dean, R.G. (2012) Comparisons at Tide-Gauge Locations of Glacial Isostatic Adjustment Predictions with Global Positioning System Measurements. Journal of Coastal Research, 28, 739-744. http://dx.doi.org/10.2112/JCOASTRES-D-11-00227.1

[67] Mörner, N.-A. (1996) Sea Level Variability. Zeitschrift für Geomorphologie, 102, 223-232.

[68] Mörner, N.-A. (2013) Patterns in Seismology and Palaeoseismology, and Their Application in Long-Term Hazard Assessments-The Swedish Case in View of Nuclear Waste Management. Pattern Recognition in Physics, 1, 75-89. http://dx.doi.org/10.5194/prp-1-75-2013

[69] Mörner, N.-A. (2010) Some Problems in the Reconstruction of Mean Sea Level and Its Changes with Time. Quaternary International, 221, 3-8. http://dx.doi.org/10.1016/j.quaint.2009.10.044

[70] CU Sea Level Research Group. http://sealevel.colorado.edu/faq\#n3113

[71] Broecker, W.S. (1962.) The Contribution of Pressure-Induced Phase Changes to Glacial Rebound. Journal of Geophysical Research, 67, 4837-4842. http://dx.doi.org/10.1029/JZ067i012p04837 